\title{
PENERAPAN SANKSI PIDANA PENYALAHGUNAAN NARKOTIKA YANG DILAKUKAN ANAK DIBAWAH UMUR ( Studi Perkara No.18/Pid.Sus-Anak/2016/PN Smg )
}

\author{
Barokah \\ Fakultas Hukum, Universitas Stikubank (UNISBANK) Semarang \\ E-mail : barokahnm16@gmail.com, rochmani@edu.unisbank.ac.id
}

\begin{abstract}
ABSTRAK
Penerapan sanksi bagi anak tidak sama dengan penerapan sanksi bagi orang dewasa, sanksi pidana yang dijatuhkan kepada anak didasarkan pada keadilan, kebenaran, kesejahteraan, serta masa depan anak, anak mempunyai ciri dan sifat khusus yang memerlukan pembinaan dalam rangka menjamin pertumbuhan fisik dan mentalnya secara utuh, selaras dan seimbang karena anak merupakan pilar terpenting dalam menentukan nasib bangsa dan negara di masa yang akan datang. Pecandu atau penyalahguna narkotika dalam perspektif hukum disebut juga seorang pelaku tindak pidana. Dalam penelitian ini penulis mengangkat beberapa permasalahan yaitu Bagaimana Penerapan Sanksi Pidana Terhadap Anak penyalahguna Narkotika dan Bagaimana Pertimbangan Hakim Dalam Menjatuhkan Putusan terhadap penyalahguna Narkotika Dalam Putusan No.18/Pid.Sus-Anak/2016/PN Smg. Metode penelitian yang digunakan dalam penelitian ini adalah in concreto. Penulisan ini bertujuan untuk menjelaskan Penerapan Sanksi Pidana Terhadap Anak Penyalahguna Narkotika dan Pertimbangan Hakim Dalam Menjatuhkan Putusan Terhadap Penyalahguna Narkotika Dalam Putusan No.18/Pid.Sus-Anak/2016.PN Smg, terdakwa dijatuhi hukuman sanksi tindakan yaitu dengan rehabilitasi medis dan rehabilitasi sosial. Sanksi yang diperoleh pelaku tindak pidana narkotika dalam putusan No.18/Pid.Sus-Anak/2016/PN Smg sudah sesuai dengan peraturan yang ada di Indonesia, selain didampingi orang/wali, terdakwa didampingi Penasehat Hukum yaitu Rizka Abdurrahman S.H,M.H, selama proses pemeriksaan terdakwa tidak mendapat perlakuan deskriminasi/pembedaan, Hakim dalam menjatuhkan putusan bagi terdakwa sudah mempertimbangkan hal-hal yang memberatkan dan meringankan serta mempertimbangkan segala sesuatu yang terbaik bagi anak.
\end{abstract}

Kata Kunci : Anak, Narkotika, Penyalahgunaan, Penerapan Sanksi Pidana 


\begin{abstract}
The application of sanctions for children is not the same as the application of sanctions for adults, criminal sanctions imposed on children are based on justice, truth, welfare, and the child's future, children have special characteristics and characteristics that require guidance in order to ensure their physical and mental growth as a whole., harmonious and balanced because children are the most important pillar in determining the fate of the nation and state in the future. An addict or narcotic abuser from a legal perspective is also a criminal offender. In this study, the authors raised several problems, namely How to Implement Criminal Sanctions Against Children of Narcotics Abusers and How Judges Considerations in Deciding Narcotics Abusers in Decision No.18 / Pid.Sus-Anak / 2016 / PN Smg. The research method used in this research is in concreto. This writing aims to explain the Application of Criminal Sanctions Against Narcotics Abuse Children and Judge Considerations in Dropping Decisions Against Narcotics Abuse in Decision No.18 / Pid.Sus-Anak / 2016.PN Smg, the defendant is sentenced to sanctions for actions namely by medical rehabilitation and social rehabilitation. The sanctions obtained by narcotics criminal offenders in decision No.18 / Pid.Sus-Anak / 2016 / PN Smg are in accordance with existing regulations in Indonesia, apart from being accompanied by a person / guardian, the defendant is accompanied by a legal advisor, namely Rizka Abdurrahman $\mathrm{SH}, \mathrm{MH}$, during the examination process of the defendant did not receive discriminatory treatment / distinction, the judge in passing the verdict for the defendant has considered things that are burdensome and lighten and consider everything that is best for the child.
\end{abstract}

\title{
Keywords : Children, Narcotics, Abuse, Application of Criminal Sanctions
}

\section{Pendahuluan}

Banyaknya kasus tindak pidana yang dilakukan anak semakin marak terjadi, Pemberian sanksi pidana yang diberikan kepada anak yang berkonflik dengan hukum harus sesuai dengan prinsip perlindungan hak anak, agar tidak mengganggu hak anak untuk tumbuh dan berkembang dengan semestinya.

Penerapan sanksi terhadap pelaku tindak pidana penyalahgunaan Narkotika tidak hanya diberikan kepada orang dewasa saja, melainkan diterapkan pada anak pelaku tindak pidana. Dalam hal anak sebagai pelaku tindak pidana penyalahgunaan Narkotika, digunakan Undang-undang sistem peradilan pidana Anak untuk menerapkan sanksi pidana terhadap anak yang berkonflik dengan hukum. Alasan menggunakan Undang Undang Sistem Peradilan Pidana Anak agar hak-hak anak selagi menjalani proses hukum tetap dapat terpenuhi dan terlindungi.

Sanksi pidana yang dijatuhkan kepada anak didasarkan pada kebenaran, keadilan, dan kesejahteraan anak. Penjatuhan sanksi tindakan merupakan suatu tindakan yang harus mempertanggung jawabkan dan 
bermanfaat bagi anak. Hakim wajib mempertimbangkan keadaan anak, keadaan lingkungan dan laporan pembimbing kemasyarakatan.

Pasal 55 ayat (1) Undangundang No.35 Tahun 2009 Tentang Narkotika "Orang tua atau wali Pecandu Narkotika yang belum cukup umur wajib melaporkan pusat kesehatan masyarakat, rumah sakit dan /atau lembaga rehabilitasi medis dan rehabilitasi sosial yang ditunjuk oleh Pemerintah untuk mendapatkan pengobatan dan /atau perawatan melalui rehabilitasi medis dan rehabilitasi sosial. $^{1}$

Berdasarkan uraian dari latar belakang diatas maka dapat ditarik beberapa rumusan masalah yaitu sebagai berikut :

1. Bagaimana Penerapan Sanksi Terhadap Anak Penyalahguna Narkotika?

2. Bagaimana Pertimbangan Hakim Dalam Menjatuhkan Putusan Terhadap Penyalahguna Narkotika Dalam Putusan No.18/Pid.Sus-Anak/2016/PN

Smg?

\section{Metode Penelitian}

Penelitian

"PENERAPAN SANKSI PIDANA PENYALAHGUNAAN

NARKOTIKA YANG DILAKUKAN ANAK DIBAWAH UMUR (Studi Perkara No. 18/Pid.Sus-Anak/2016/PN Smg)" ini merupakan suatu penelitian

\footnotetext{
${ }^{1}$ Ruslan Renggong, 2017, Hukum Pidana Khusus Memahami Delik-Delik di Luar KUHP. Jakarta : Kencana, ,hal.131-132.
}

hukum dengan menggunakan metode pendekatan yuridis normatif.

Fokus penelitian menggunakan penelitian secara in concreto, yaitu penelitian untuk menemukakan hukum bagi suatu perkara. Data yang dikumpulkan adalah data yang berhubungan dengan peraturan perundang-undangan yang berlaku, yakni Undang-Undang Nomor 35 tahun 2009 tentang Narkotika, Undang-Undang Nomor 11 tahun 2012 tentang Sistem Peradilan Pidana Anak, serta akan ditinjau pula dengan teoriteori yang berkaitan di dalam perlindungan hakim dan pertimbangan hakim dalam menjatuhkan sanksi pidana terhadap anak, serta pengumpulan data dalam penelitian ini menggunakan studi pustaka dan wawancara.

\section{Pembahasan}

\section{Bagaimana Penerapan Sanksi Terhadap Anak Penyalahguna Narkotika?}

Penerapan Sanksi untuk anak hanya dapat dijatuhi sanksi yang berupa sanski pidana atau sanksi tindakan. Dalam kasus ini, penerapan sanksinya berupa sanksi tindakan, yaitu dengan diserahkan ke Balai Rehabilitasi Sosial di Balai Rehabilitasi Sosial Eks Penyalahgunaan Napza "Mandiri" Semarang.

Tindak pidana penyalahgunaan narkotika yang dilakukan telah memenuhi unsurunsur tindak pidana dalam pasal 127 ayat ( 1 ) huruf a Undangundang Nomor 35 Tahun 2009 Tentang Narkotika. 


\begin{abstract}
Pelaku penyalahguna narkotika merupakan pelaku sekaligus korban, hal ini disebabkan karena tidak adanya korban yang dirugikan selain pelaku sendiri, maka dari itu diversi yang berupa rehabilitasi bagi terdakwa sangat sesuai karena pada dasarnya penentuan hukum berupa penentuan sanksi bertujuan untuk :
\end{abstract}

a. Mencegah perilaku anak lebih buruk dikemudian hari, sehingga menjadi manuasia yang baik dan berguna;

b. Memberikan perawatan dan perlindungan untuk keselamatan, kesejahteraan, dan kesehatan bagi anak;

c. Membebaskan rasa bersalah serta menghapus stigma buruk pada anak;

d. Menciptakan kondisi lingkungan yang baik bagi tumbuh kembang jiwa anak dan dapat meningkatkan taraf hidup yang baik bagi perkembangan fisik, mental, maupun sosial. ${ }^{2}$

Pasal 3 Undang-undang Sistem Peradilan Anak menyatakan bahwa Setiap Anak yang berhadapan dengan hukum berhak diperlakukan secara manusiawi dan harus diperhatikan kebutuhan sesuai umurnya serta tidak boleh diperlakukan sema dengan orang dewasa, anak harus dipisahkan dari

\footnotetext{
${ }^{2}$ Nandang Sambas, 2010, Pembaharuan Sistem Pemidanaan Anak di Indonesia., Yogyakarta : Graha Ilmu, Hal.213
}

orang dewasa dan memperoleh bantuan hukum.

Dalam Putusan Pengadilan

No. 18/Pid.Sus-Anak/2016/PN

Smg anak Rizky Atala Putra bin Paryono sudah memperoleh hakhaknya di dalam proses peradilan, selain di damping orang tua/wali terdakwa didampingi oleh Penasehat Hukum atau Pengacara yang ditunjuk oleh Pengadilan Negeri Semarang, dan Rizky Atala Putra selama dalam proses pemeriksaan tidak di lakukan penahan dan deskriminasi/pembedaan.

Rehabilitasi merupakan hak dari penyalahguna narkotika. Melalui rehabilitasi diharapkan pengguna narkotika dapat dipulihkan kembali kondisi fisik maupun mentalnya kembali kedalam semula ketika sebelum menggunakan narkotika. Berbeda dengan pidana penjara, dasar pemberian rehabilitasi lebih menitik beratkan pada pemulihan kondisi pengguna, sedangkan penjara lebih kepada efek jera.

Sampai saat ini belum ada penelitian yang menunjukan bahwa pidana penjara telah menghasilkan upaya perbaikan bagi sipelaku, pada kenyataannya menunjukan sebaliknya. Dengan dijatuhkan pidana penjara pagi pengguna narkotika tidak menjadikan sosok yang lebih baik dan berefek jera, bahkan pengguna narkotika tersebut menjadi lebih buruk karena dia tidak hanya berkumpul dengan sesama pelaku kejahatan pengguna narkotika lainnya. 
2. Pertimbangan Hakim Dalam Menjatuhkan Putusan Terhadap Penyalahguna Narkotika Dalam Putusan No.18/Pid.Sus-Anak/2016/PN Smg

Putusan Hakim sangat tergantung pada informasi atau bahan-bahan yang diberikan oleh Kepolisian dan Kejaksaan, sebelum Hakim memutus suatu perkara, termasuk penyalahguna narkotika, dalam putusannya sangat dipengaruhi oleh berkasberkas yang berupa Berita Acara Perkara dari kepolisian, serta surat dakwaan dan tuntutan yang dibuat oleh jaksa penuntut umum, meskipun tidak sepenuhnya putusan hakim dipengaruhi oleh hal tersebut. Hakim dalam menjatuhkana putusan harus bersifat memperbaiki. Hakim harus memberikan hukuman yang tepat dan terbaik untuk anak karena keputusan hakim akan mempengaruhi kehidupan anak selanjutnaya. ${ }^{3}$ Ketentuan mengenai penerapan sanksi Pidana hakim dalam menjatuhkan putusan pidana diatur dalam Pasal 197 ayat (1) d KUHAP yang dirumuskan sebagai berikut, "Pertimbangan hakim disusun secara ringkas mengenai fakta dan keadaan beserta alat pembuktian yang diperoleh dari pemeriksaan persidangan yang menjadi dasar penentuan kesalahan-kesalahan terdakwa. ${ }^{4}$

\footnotetext{
${ }^{3}$ Wawancara dengan Hakim Hakim Fatchurrochman, S.H di pengadilan Negeri Semarang tanggal 15 April 2019

${ }^{4}$ Pasal 197 ayat (1) d KUHAP
}

Hakim dalam menjatuhkan putusan pidana terhadap anak menggunakan pertimbangan yang bersifat yuridis dan non-yuridis.

\section{a. Pertimbangan Yuridis}

Pertimbangan Yuridis adalah pertimbangan hakim yang didasarkan pada faktor-faktor yang terungkap dalam persidangan dan oleh Undangundang telah ditetapkan sebagai hal yang harus dimuat dalam putusan. Pertimbangan yuridis dalam putusan pengadilan No.18/PIid.Sus.Anak/2016/ PN Smg antara lain : Pertimbangan fakta dan pertimbangan hukum hakim membuktikan dakwaan penuntut umum dengan mendatangkan saksi-saksi yang telah memberikan keterangan dibawah sumpah yaitu saksi Tyas Cahya Yuda dan saksi Yudi Sutardi, sebagai Anggota Unit III Sat Resnarkoba Polrestabes Semarang, saksi Gussri Dwi Handoko Als.Betet \& saksi Muhamad Eko Budi Prasetyo sebagai teman yang memberikan sabu secara Cuma-Cuma. Dan mengkonsumsi sabu bersamasama. Keterangan Terdakwa : membenarkan keterangan dari para saksi. Barang bukti : satu kantong palstik klip berisi sabusabu. Setelah mendengar keterangan keterangan saksi, serta keterangan terdakwa dan alat bukti yang diajukan dipersidangan , disimpulkan bahwa antara satu dengan yang lainnya saling bersesuaian dan berhubungan. 


\section{b. Pertimbangan Non-Yuridis}

Pertimbangan non-yuridis adalah pertimbangan hakim yang di dasarkan oleh keyakinan hakim, dan tidak berdasarkan bukti-bukti yang ada yang menekankan kepada kemanfaatan bagi masyarakat. ${ }^{5}$ Pertimbangan non-yuridis dalam hal ini berhubungan dengan pelaku, antara lain: pendidikan, posisi pelaku dalam keluarga, dan perilaku pelaku dalam bersosialisasi dengan lingkungan. Dari fakta yang penulis dapatkan dari Putusan Pengadilan, terdakwa menyatakan bahwa terdakwa mengkonsumsi Narkotika karena ajakan teman yang memberinya secara CumaCuma karena pertemanan.

Berdasarkan pengamatan Hakim selama persidangan dengan mempertimbangkan Halhal yang memberatkan dan halhal yang meringankan yaitu : Hal-hal yang meringankan, yaitu : terdakwa masih anak dibawah umur, terdakwa mengakui perbuatannya dan menyesalinya, terdakwa belum pernah dihukum, terdakwa mengkonsumsi narkotika karena ajakan teman. Hal-hal yang memberatkan, yaitu : perbuatan terdakwa bertentangan dengan program pemerintah yang giat-giatnya memberantas Narkoba, maka menurut Hakim terdakwa lebih tepat dan bijaksana apabila dijatuhi sanksi tindakan yaitu dengan rehabilitasi medis dan rehabilitasi social.

Gustav

Radbruch mengemukakan bahwa, hukum idealnya disusun dengan 3 ( tiga ) nilai yaitu : kepastian hukum, kemanfaatan hukum, dan keadilan, begitu pula keputusan yang akan dikeluarkan oleh hakim, walaupun dalam kenyataannya sangat sulit untuk mewujudkan tiga nilai tersebut karena selalu terdapat benturan antar tiga nilai tersebut sehingga harus ada nilai yang diproiritaskan dan dikorbankan. Sistem pembuktian yang diterapkan Majelis Hakim untuk terdakwa anak Rizky Atala Putra bin Paryono dalam perkara No.18/Pid.Sus-

Anak/2016/PN.Smg sudah sesuai dengan landasan teori hukum yang diatur dalam Pasal 183 KUHAP dan Pasal 103 Undangundang Narkotika Nomor 35 tahun 2009 tentang Narkotika. Pada hakikatnya tujuan dari adanya peradilan anak ini adalah untuk memberikan perlindungan hukum bagi anak pelaku tindak pidana untuk diperlakukan secara manusiawi sebagai anak-anak, dan putusan yang dijatuhkan oleh hakim bertujuan untuk mendidik anak agar memperoleh hikmah dari kesalan yang telah dibuatnya.

Melalui pertimbangan Hakim dapat dinilai keabsahannya, dan indikator dari keadilan suatu putusan juga dapat dilihat bagaimana pertimbangan yang 
dipakai hakim, hendaknya harus berdasarkan yang rasional dan sesuai dengan fakta yang ada. Profesionalisme yang meliputi pengetahuan dan keahlian / keterampilan yang ditunjang dengan ketekunan dan ketelitian merupakan salah satu hal yang mempengaruhi hakim dalam mengambil keputusan. Profesionalisme sering dikaitkan dengan kode etik di lingkungan peradilan, oleh sebab itu hakim yang berpegang teguh pada etika profesi akan menghasilkan putusan yang lebih dapat dipertanggungjawabkan,

dibanding dengan hakim yang kurang mengindahkan etika profesi, sekalipun keduanya memiliki tujuan yang sama yaitu menyelesaiakan perkara dan menegakakan hukum.

\section{Simpulan}

Penerapan sanksi pidana terhadap anak penyalahguna narkotika yang dilakukan Rizky Atala Putra berupa sanksi tindakan yaitu rehabilitasi medis dan rehabilitasi sosial. Sanksi yang diperoleh pelaku tindak pidana narkotika dalam putusan pengadilan No.18/Pid.SusAnak/2016/PN Smg sudah sesuai dengan peraturan yang ada di Indonesia, selain di damping orang tua/wali terdakwa didampingi Penasehat Hukum yaitu Rizka Abdurrahman,SH.MH,. Selama dalam proses pemeriksaan terdakwa tidak mendapatkan perlakuan penahanan, deskriminasi/pembedaan, Hakim dalam menjatuhkan putusan bagi terdakwa sudah mempertimbangkan segala sesuatu yang terbaik bagi anak serta memperhatikan perkembangan anak untuk masa depannya seperti pendidikan dan perhatian orang tua.

Pertimbangan hakim dalam menjatuhkan putusan terhadap penyalahguna narkotika dalam putusan No.18/Pid.Sus-Anak/2016/PN Smg, menggunakan pertimbangan yang bersifat yuridis dan non-yuridis. Hakim dalam menjatuhkan putusannya hakim melihat segala hal sesuatu yang terbaik buat anak dan bersifat memperbaiki karena putusan Hakim akan mempengaruhi kehidupan anak dimasa yang akan datang.

\section{Saran}

Berdasarkan hasil penelitian yang dikemukakan di atas, maka saran yang diberikan adalah:

a. Pengaturan sanksi pidana dalam Undang-undang Nomor 35 Tahun 2009 Tentang Narkotika sudah seharusnya direvisi, guna memasukan beberapa pasal terkait anak yang melakukan tindak pidana narkotika. Hal ini ditujukan untuk penerapan sanksi bagi pelaku tindak pidana Narkotika, agar dalam menjalani rehabilitasi sosial dan rehabilitasi medis dengan minimal satu tahun, dan maksimal tiga tahun agar pelaku tindak pidana Narkotika benar-benar merasakan efek jera dan benabenar terlepas dari Narkotika. Pengaturan ini bertujuan untuk memberikan kepastian terhadap Hakim dalam menjatuhkan putusan pidananya. 
b. Seharusnya penerapan sanksi tidak hanya diberikan kepada anak sebagai pelaku tindak pidana narkotika saja, melainkan orang tua atau wali dari anak pelaku tindak pidana Narkotika juga harus diberikan sanksi tindakan yaitu berupa rehabilitasi sosial atau edukasi mengenai bahayanya Narkotika dan edukasi dalam mendidik anak.

c. Agar diadakannya pendidikan atau edukasi terhadap Ibu-ibu PKK (Pemberdayaan Kesejahteraan Keluarga), mengenai bahaya Narkotika beserta sanksinya. Karena Ibu adalah madrasah pertama dan terbaik bagi anak

\section{Daftar Pustaka}

Renggong Renggong, 2017, Hukum Pidana Khusus Memahami Delik-Delik di Luar KUHP. Jakarta : Kencana.

Nandang Sambas, 2010, Pembaharuan Sistem Pemidanaan Anak di Indonesia., Yogyakarta : Graha Ilmu.

Wawancara dengan Hakim Hakim Fatchurrochman, S.H di pengadilan Negeri Semarang

Kitab Undang Undang Hukum Acara Pidana 